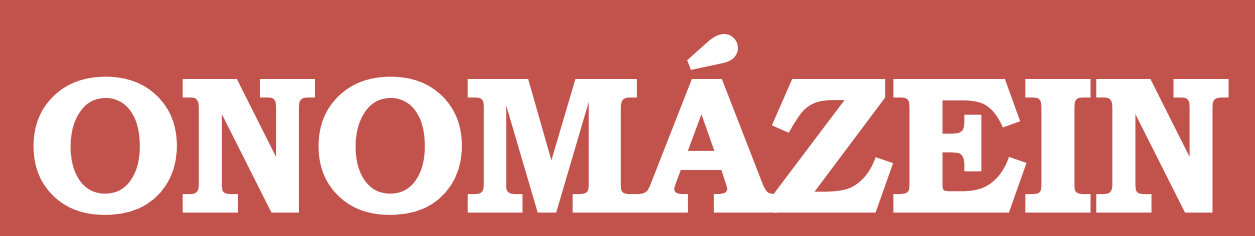

Journal of linguistics, philology and translation
PONTIFICIA UNIVERSIDAD

\title{
Use and perception of code switching by students and instructors in the second language classroom in the US
}

\section{Slávka Mad'arová}

Universidad de Alcalá

España

\section{(C) $($ (i) $\ominus$}

Slávka Mad'arová: Departamento de Filología Moderna, Universidad de Alcalá, España | E-mail: s.madarova@edu.uah.es 


\section{Abstract}

Code switching is a phenomenon that has increasingly attracted more and more attention from the linguistic community. As of last forty years, it is no more deemed as a deficiency in speech, but rather as a separate area of research. However, to obtain data for further examination that would not be manipulated by priming the subjects is quite complicated and poses a challenge in creating a corpus that could be used by researchers. This paper offers examples of code switching that were produced in a second language classroom in a large public university in southwestern United States. Three levels of class, from beginner up until intermediate level, were observed and recorded. Each of the instructors - a native speaker of Spanish, a native speaker of English and an early balanced bilingual_offered their insights into the use and perceptions of code switching practice in the classroom. This observation provided a framework of reference to better understand the process that takes place in a bilingual environment of a second language classroom.

Keywords: code switching; intra-sentential/extra-sentential switching; tag switching; early/ late/balanced bilingual; second language classroom. 


\section{Introduction}

In the interview on bilingualism, published on his webpage, Francois Grosjean-an expert in the area-said: "bilingualism is extremely widespread and is the norm in today's world (and not the exception)" (Grosjean, 2002: §6). Views on bilingualism are constantly moving away from the statement that defines a bilingual person as two monolinguals in one. This shifting view consequently sheds more light on the phenomenon of code switching.

Perceived in the past as a failed attempt at mastering one of the two languages that bilinguals speak, code switching is nowadays looked at as an interesting area of research. However, study of code switching is rather complicated since simulated conditions do not provide same results as observation in natural situations. One area that offers a possibility of observing such phenomenon without simulating natural conditions is the second language learners' classroom.

Research in the field of code switching demonstrates that both students and instructors in the second language classroom are known to engage in the practice of code switching. While students usually present a homogeneous group from the point of their language proficiency and operate under certain constraints of peer pressure, instructors possess the adequate training and experience that allows them to reflect on their use of code switching in the classroom. To that end, a decision has been taken to accompany the classroom observation with the examination of the viewpoint of instructors who proceed from different language backgrounds and to use their insights to gain better understating of the cS practice in the second language classroom.

Consequently, the aims of this paper are: first, to identify and observe the use of code switching in the second language classroom; second, to determine if the instructor's native language influences code switching practice in the classroom, and, finally, to examine if there is a relationship between code switching and second language learners' proficiency. To do this, this research records and analyses data obtained from observation of usual classroom activity and establishes the use and perception of code switching based on the interviews with the instructors. Thus, the research questions are the following: 1) What is the aim of code switching in second language classroom? 2) Does the instructor's native language influence their code switching practice? 3) Is there a relationship between code switching and proficiency of second language learners?

In order to find answers to these questions, the paper is organized into two main sectionstheoretical and practical. The theoretical part in its subsections includes definitions and categorization of code switching. It also gives a short overview of bilinguals and of second language classroom. The practical part of the research focuses on the examples of code switching obtained via recordings of class activities, performed by both the students and instructors. Finally, transcripts of interviews with instructors included after the examples 
shed some light on the use and perception of their code switching practice in the second language classroom.

\section{Concepts related to code switching and second language classroom}

\subsection{Definition of code switching}

Code switching (hereafter CS) as a term was used for the first time by Hans Vogt in his article from 1954; however, CS as a subject of research was of little importance during the 1950s (Auer, 1998). Experts in the field offer various definitions of this phenomenon. Grosjean (1982: 145) defines CS as "the alternate use of two or more languages in the same utterance or conversation". Muysken (2000: 1) uses a slightly different approach and describes it as "the rapid succession of several languages in a single speech event". CS itself is not limited to bilingual or multilingual speakers only but it also refers to switching between dialects in monolingual speech.

Several concepts appeared during the outlining phase of CS research. In 1962, Hansegård established a new term in regards to development of CS-'semilingualism'. In his understanding, it denominated a bilingual individual that was not proficient in either of two languages (MacSwan, 1999). A number of researchers followed his example and supported the idea that CS is a sign of not being able to cope efficiently with two languages at the same time. This notion was prevalent mainly in studies focusing on immigrant children as mentioned by Hinnenkamp in his research paper published in 2005 where he discusses how CS under the name of 'semilingualism' was made into a label used in second language education of these children. It remained popular until the 1980s, when works of linguists such as Poplack and Gumperz, who looked at patterns of CS between certain language pairs and concept of CS grammar, came into the center of attention (Auer, 1998).

The perception of CS in the contemporary society largely depends on the situation where CS occurs. As mentioned by Gardner-Chloros (2009: 172), "studies of attitudes toward it generally show it to be a stigmatized form of speech". Bullock and Toribio (2009: 1) state that perception of CS practice oscillates based on the audience and mention the use of the term 'language degeneration', the still popular notion that CS is based on inability of multilingual language speakers. Furthermore, language teachers thorough their training are discouraged from using CS in their teaching process.

Clear denomination of term CS is somewhat problematic. Due to its characteristics CS has been compared by some researchers such as Treffers-Daller (2009: 59) to transfer since it involves "the wide variety of phonological, morphological, syntactic, semantic, and conceptual features, lexical items, phrases, clauses, multiword chunks, and graphemic symbols that can be transferred from one language to another". 
CS can be looked at from two viewpoints. Prescriptive grammar implies looking for rules that can be applied to the usage of CS. For example, the variation approach looks at CS that usually occurs between languages that share the same grammatical structure, therefore the same grammatical rules. However, this approach runs into difficulties as soon as the members of the language pair belong to languages as different as English and Swahili (Gardner-Chloros, 2009). Therefore, although in prescriptive grammar CS is deemed as a mistake since it circumvents the traditional norms of language, descriptive grammar considers CS as a field of study (Bullock and Toribio, 2009).

Approaches to the study of CS can be classified in three main groups. Gardner-Chloros (2009: 10) proposes division based on their focus: conversation analytic approach aimed at interlocutors, grammatical analysis directed at the search for rule and the third approach that centers on the sociolinguistic/ethnographic descriptions of CS situations, where the factors that influence CS stem from the social identity and life of the individual. Since one of the goals of this study would be to get better understanding of how CS is produced, employing psycholinguistic approach could be also considered.

However, psycholinguistic methods, albeit significant in research of relationship between the mind and language, focus on investigating the occurrence of CS in controlled environment. This means that the subjects are asked to react to predefined CS examples. To avoid this situation, a decision was taken to focus on CS in more natural surrounding - the second language (L2) classroom. Therefore, this paper records the CS examples produced both by instructors and by language learners during the teaching process, without interference from the researcher.

\subsection{Categorization of code switching}

CS, despite the public perception, is "not the random mixing of two languages" (Bullock and Toribio, 2009: 4). CS practice follows certain structure and can be classified according to its most prominent features. Poplack's categorization cited in Bullock and Toribio (2009: 3) divides CS into two major groups-inter-sentential, where the switch occurs on the level of clauses, and intra-sentential, which refers to switching between two languages within the same sentence.

Muysken (2000) further recognizes three distinct categories-insertion, alternation and congruent lexicalization. Insertion covers the process when a word or a noun phrase from L1 is inserted into $L 2$ in a similar way that occurs in case of borrowing - it is an equivalent to embedding of an element from base language into matrix language, following the A-B-A pattern. This is illustrated by the example put forward by Pfaff (1979: 296): "Yo anduve in a state of shock por dos días".

Alternation is what Muysken considers as the closest to the phenomenon of CS. When alternation is produced, speakers switch between the L1 and L2 within the same sentence in a way 
that one part of the sentence is seamlessly replaced by another - LI for L2 or vice versa, as can been seen here: "Me estaba defendiendo and then he split" (Pfaff, 1979: 312). Alternation basically means that one language takes the place of another, in an A-B pattern.

The last category is the congruent lexicalization where elements from both $L 1$ and $L 2$ share grammatical structure and therefore can be inserted in the same sentence, usually randomly, according to A-B-A-B pattern (Muysken, 2000). In the corpus compiled by Pfaff (1979: 310) the following example demonstrates the category: "Bueno, in other words, el flight que sale de chicago around three o'clock".

Lastly, the phenomenon called tag-switching, defined as "[an] insertion of a formulaic expression from one language $B$ into an utterance in language $A$ ", is particularly interesting for the purpose of this research since authors assigned it to bilinguals who are not fully proficient in L2 (Bullock and Toribio, 2009: 4). Expressions such as 'ok', 'well', 'you know' are all examples of tag switching. There is an expectation that those expressions will occur within the recorded classroom activity.

\subsection{Bilingual speakers of languages}

For the purpose of this project, it is necessary to distinguish different categories of bilinguals when it comes to the instructors. Bullock and Toribio (2009: 7) offer the following definition: 'simultaneous' or 'early bilinguals' are individuals who acquired second language as children and maintained it during their lifetime. Second language acquirers, also called 'late bilinguals', are individuals who already mastered their first language when they were exposed to the second language. The 'elite bilinguals', who have learned their second language through formal schooling, belong to this group.

Late bilinguals usually suffer from a phenomenon called 'crutching', caused by "temporary or permanent lapses in knowledge", where speakers are often unable to express themselves in L2 and revert back to LI (Bullock and Toribio, 2009: 9). Muysken (2000) also comments on the extent of bilingual proficiency on CS production and concludes that balanced bilinguals will predominantly produce examples from the category of intra-sentential CS. As Hancock (1997) mentions in his article about group work in L2 classroom, there are two types of situations when $\mathrm{L} 1$ is interjected into L2-one stems from the interaction of the students in the dialog while the other is caused by purely repeating L2 phrases without understanding.

\subsection{Second language (L2) classroom environment}

The choice of a teaching method in the second language classroom generally depends on the instructor, institution, level of class and teaching material. The observed L2 classrooms listed in the practical part of the research intend to provide their students with communicative knowledge of Spanish language. Function of CS in such L2 classroom is twofold_dis- 
course-related and participant-related. The first one helps the student to overcome shortcomings within their $\mathrm{L} 2$ while the second one is used mostly by instructors within their teaching, where they can move in and out of the teaching context, as mentioned by Liebscher and Dailey-O'Cain in their article "Learner Code-Switching in the Content-Based Foreign Language Classroom" (2005).

Additionally, it is important to remark on the situation related to teaching Spanish in the US. According to Barnwell (2008), the most popular foreign language to learn in US nowadays is Spanish; however, very few students reach proficiency during their college career. Barnwell in his article says that "despite sporadic signs to the contrary, however, the United States remains a predominantly monolingual society, or at least one in which languages other than English are marginalized" (2008: 241). This leads into the concept of motivation for language learning. Bazo (1996: 59) in A Handbook for EFL defines integrative motivation as "the desire to achieve proficiency in the $\mathrm{L} 2$ in order to become an accepted member of the target language community".

Since students do not have the possibility to practice L2 outside the classroom, they rely more on the concept of instrumental motivation, where $L 2$ is required for practical purposes such as travel or a work position. As Barnwell (2008) further mentions in his article, students usually enroll in lower level language courses despite the fact that some of them have been studying Spanish in secondary and high school-a reason for classes oriented more towards 'technical aspects' of the language such as grammar and exercises instead of providing an overall picture of related culture and literature.

\section{Practical part of the research}

\subsection{Research method}

The practical part of the research consisted of observing Spanish language classroom in a large public university in southwestern United States during one week in April 2017. Classroom observation used in this study can be defined as gathering of naturalistic data through recording in a particular setting (i.e., the classroom interaction) and subsequent creation of a bilingual corpus as mentioned by Gullberg et al. (2009). The aim of this qualitative study was to observe CS occurrences in Spanish in a second language classroom environment carried out by students and their instructors.

Two sections of the class, within the same level and with the same instructor but different set of students, were observed and recorded on the same day. The size of the section varied between eight and nineteen students. The researcher did not intervene in any way in the classroom process. Simultaneously with recording, field notes observation form was used with the aim of highlighting the most prominent examples of CS. This was an electronic 
form designed by the researcher to note time, class activity and person carrying out the CS-either instructor or student.

In addition, a second component of the study consisted of interviewing three instructors whose classes were observed. Semi-structured interviews were carried out after the class observation to avoid priming of the instructor prior to the class. The reason behind this decision was that the perception of their own CS practice would be influenced by the interview questions.

\subsection{Data collection}

Since recording of class activity falls into the category of 'Research with human subjects', permission was sought and obtained from the Institutional Review Board (IRB) of the university. This step has been completed in order to carry out the observations and recordings necessary for the study and prior to its start. The researcher did the transcriptions of class recording and interview recordings with instructors directly. Letter code and number only (I-1, I-2 and I-3 for instructors and $\mathrm{S}$ for students) identified each participant of the recording. Audio-recorded data was stored during the length of the study and deleted once transcription was completed.

Instructors were approached directly and asked for permission to observe their class and to participate in the short interview. A semi-structured interview was conducted with each individual instructor after the class and audio recorded. Student participants were not to be identified in this study and no personal data of student participants was collected. Therefore, there was no need to obtain written permission from each student. The researcher made an announcement at the beginning of the class to explain her presence, informing students about the recording and giving them opportunity to refuse being recorded.

\subsection{Examined selection}

The second language classes chosen for this research belonged to three different levels, from beginner to intermediate. Students in these classes were native speakers of English (LI) learning and practicing Spanish (L2). Each class used different teaching material and had a different instructor. I argue that the language level of students and used course material should have an influence on the occurrence of CS.

The instructors chosen for this research-early balanced bilingual (I-1), native speaker of Spanish (I-2) and native speaker of English (I-3)-provided three different levels on which CS could be evaluated. This selection has been made to observe the influence of mother tongue on the process of CS performed by each of the instructors, in typologically similar languages such as English and Spanish. This is related to the language dominance, which should be different for each instructor, since the dominant language would be each instructor's native language-L1 (Basnight-Brown and Altarriba, 2007: 79). Moreover, Muysken (2000: 224-225) mentions the notion of 'bilingual proficiency' when talking about the adult bilingualism. Re- 
lated research on CS in bilingual language communities points towards the higher frequency of use of intra-sentential code switching in the form of congruent lexicalization, based on the high proficiency in both languages as well as more frequent occurrence of tag-switching. In case of lower proficiency, the tendency is to use simple insertion and alternation.

In line with the concept of bilingual proficiency, I argue that in the case of a non-native speaker of Spanish, CS should occur in the way of simple insertions and alternation, as a bridge or a crutch to help the instructor overcome a linguistically difficult situation. Furthermore, due to the dominant language of the instructor being English, the instructor should feel more comfortable speaking it. In the case of a native speaker of Spanish, the code switch would be from Spanish - the dominant language - to English, which is not the first language of the instructor. Therefore, English should be used for emphasis only, most probably in the form of tag switching, since the instructor would have an access to a wider range of vocabulary to describe the concept for students without the need to resort to insertion or alternation.

However, in the case of the balanced early bilingual, even though according to bilingual proficiency there is a heightened possibility of CS use, it is not possible to determine with certainty the dominant language. As mentioned by Basnight-Brown and Altarriba (2007: 79), balanced early bilinguals in the US "appear to show a shift in language dominance, such that their L2 (English) tends to become their more dominant language". Therefore, I argue that the balanced early bilingual instructor should be comfortable with both English and Spanish language to such level that the CS in the classroom-if it occurs at all-would be a result of conscious choice and therefore limited.

\subsection{Transcripts}

Class observation schedule:

\section{TABLE 1}

Functions of sañani

\begin{tabular}{lllc} 
CLASS OBSERVED & TYPE OF INSTRUCTOR & MATERIAL/S USED IN CLASS & $\begin{array}{c}\text { TOTAL } \\
\text { NO. OF CS } \\
\text { EXAMPLES }\end{array}$ \\
$\begin{array}{l}\text { Beginner Level } \\
\text { Spanish }\end{array}$ & $\begin{array}{l}\text { Early balanced bilingual } \\
\text { - Spanish/English (I-1) }\end{array}$ & Textbook and exercise book & 34 \\
\hline $\begin{array}{l}\text { Continuation of } \\
\text { Beginning Spanish }\end{array}$ & $\begin{array}{l}\text { Late elite bilingual - native } \\
\text { speaker of Spanish (I-2) }\end{array}$ & $\begin{array}{l}\text { PPT presentations, a drawing } \\
\text { activity and supplemental } \\
\text { material from exercise book }\end{array}$ & 24 \\
\hline $\begin{array}{l}\text { Intermediate } \\
\text { Level Spanish }\end{array}$ & $\begin{array}{l}\text { Late elite bilingual - native } \\
\text { speaker of English (I-3) }\end{array}$ & $\begin{array}{l}\text { Video presentation } \\
\text { and exercise book }\end{array}$ & 10 \\
\hline
\end{tabular}




\subsubsection{Class observations - Beginner Level Spanish - I-1}

The observed class followed a structure based on the course work that consisted of 10 to 20 minute blocks. Around 34 examples of CS were observed; the most prominent examples are listed in this section. Spanish text appears in italics.

1. Grammar task (progressive tense) from the textbook:

I-1: ¿Qué dice de los usos? Señorita [...]?

S: Should I read number one?

I-1: [motions for student to read]

S: [reads aloud in English]

I-1: Muy bien.

- I-1 starts the grammar explanation in Spanish, then switches to the textbook and still in Spanish poses a question to one of the students. After a clarification question, the student reads aloud the grammar rule from the book written in English. When finished, I-1 praises the student in Spanish. General explanation is provided in Spanish; however, detailed explanation of grammar rule is delivered in English.

S: Only to express the action that is happening right now.

I-1: Only! En inglés tenemos what is happening right now, ¿verdad? Tenemos what is happening over period of time $y$ what is going to happen, yeah? Pero en español [...] simple present tense, right?

- I-1 explains the grammar rule in Spanish while quoting sample English sentences that appear in the textbook. His first utterance starts in Spanish, contains intra-sentential CS in English and tag-switching in Spanish. His second utterance contains intra-sentential CS in English with tag-switching in the end performed in English-a similar case occurs in the third utterance. It could be argued that the intra-sentential CS has triggered the tag-switching in the second and third utterance.

I-1: When? Never ever, porque ya tenemos aquí 'ir a’ más infinitivo.

- I-1 continues with grammar explication, using intra-sentential switching (alternation) between English for rules and emphasis and Spanish for the rest of the sentence.

S: $E, N \ldots$...K and then $A$

- The student tries to spell the Spanish word. After momentary hesitation appears tag-switching triggering switch to English and then the sentence continues in Spanish.

s: How do you use that? 
I-1: Estoy llendo a la biblioteca

- The student asks for clarification using an English phrase. Despite that, I-1 responds by presenting an example in Spanish.

I-1: OK, muy bien. Show your answer to your neighbour, comparten sus respuestas.

- After a grammar exercise, I-1 encourages students to share their answers. The first sentence starts with tag-switching functioning as a discourse marker. In the second sentence, $\mathrm{I}-1$ deliberately switches between $\mathrm{L} 2$ and $\mathrm{L} 1$ to provide translation of the sentence.

I-1: Is that possible? I don't know pero the point is that you can do that.

- I-1 performs an intra-sentential switch (insertion) by employing a Spanish connector to connect both sentences in English while preserving the sentence structure in both Ianguages.

2. Supplementary material exercises:

I-1: Número uno - what day of the week is it.

S: I put Sunday.

I-1: En español.

S: Oh, domingo.

- The exercise requires students to respond in Spanish to questions posed in Englishquestion by I-1 asked in English triggers student's response in English; however, the expected answer must come in Spanish to comply with the exercise structure-this proves quite complicated for students.

I-1: Está hablando con su amiga because that is what she is doing right now.

S: Isabel es la abuela y está jugando el ajedrez con su hija.

I-1: Isabel es la abuela, right? Y está jugando, right? Because that's what she is doing right now.

- To emphasize the grammar rule, l-1 uses the sample sentence in correct tense in Spanish and then further explains the application of the rule in English, engaging in intra-sentential CS (alternation). In the second utterance I-1 implements tag switching in form of a discourse marker 'right'.

S: Could it be reflexive?

I-1: Yeah

S: OK, so how would you...

I-1: The verb is despertarse

S: Despertarse a las diez de la tarde. 
- The student is unsure of the verb form he used, so he asks I-1 for clarification in English. Since it is a question about grammar rule, l-1 responds in the same language in which the question was posed. Once the student possesses the necessary information, the final version of the sentence is produced in Spanish.

I-1: Página setenta y nueve, exercise D. ¿Qué están haciendo en este momento? Use the present progressive.

- Students are prompted to do exercise where they have to use the present progressive tense. The first sentence in Spanish includes intra-sentential switch in English (insertion). The second and the third sentence represent inter-sentential switch (alternation).

S: El bebé están dormirse.

I-1: Está because it’s one bebé right? Unless there are two of them. Está durmiéndose, right?

- The student is reading aloud the answer to the question posed in the exercise. I-I helps the student by explaining the Spanish elements in English, performing intra-sentential switch (insertion). I- 1 then uses inter-sentential CS to correct the student and inserts tag-switching in English at the end of the Spanish sentence.

I-1: Señorita tenía really good point. Se puede decir 'se' antes de 'estar'; se está bañando ahora mismo o está bañándose ahora mismo, yeah. ¿Preguntas? [...] ¿Alguien más? Last one?

- I-1 alternates between Spanish and English in the first sentence, then uses a full sentence in Spanish with tag-switching in the end. After asking two more questions in Spanish, I-I uses inter-sentential switch to emphasise the last question, rephrasing it rather than translating it.

\subsubsection{Class observations - Continuation of Beginning Spanish - I-2}

The observed class followed a certain structure based on the course work that consisted of presentations, a drawing activity, use of supplemental material and a drawing presentation. Around 24 CS examples were observed; the most prominent examples are listed in this section. Spanish text appears in italics.

\section{1st student's class presentation:}

S: [...] in two thousand twelve [...]

I-2: ¿Cómo se dice two thousand twelve?

- When presenting, the student got confused and could not remember how to say the date. Therefore, the English version of the date was inserted in the form of intra-sentential switch. When the presentation was finished, I-2 helped the student by asking the whole 
class in Spanish how to say two thousand twelve. The presentation was not interrupted on the spot when the cS occurred.

S: Le gusta ir al parque y chasing squirrels a lot, so [...]

I-2: Ardillas

s: Yes

- The student does not know the word 'squirrel' in Spanish and performs intra-sentential switch (alternation), waiting for help from I-2, who helps the student by translating the word to 'ardilla'. However, at this point the student does not repeat it but merely says 'yes'.

S: Pie [pronounced by student as/pal/ instead of /pje/]

I-2: ¿Pie de chocolate o pie de fresa?

- Students talk about body parts. I-2 writes the word 'pie' on the blackboard. The student confuses the word by applying English pronunciation instead of Spanish, which effectively changes the meaning of the word. I-2 jokingly asks which meaning is correct. It is possible that this episode will work as a mnemonic device in order to reinforce the difference between pronunciation in English and Spanish.

2. 2nd student's class presentation:

S: And then soy de San Diego

- The student connects the first and the second part of her Spanish discourse with intra-sentential switch, inserting English.

S: ¿Cuántos hermanos tengo?

S: Two.

I-2: ;Dos!

- The student giving presentation asks the rest of the class about details that were presented earlier. Another student responds fast but in English, to which I-2 performs correction in Spanish.

S: Mi hermano y tú también vivo en San Diego.

S1: Where about?

S2: Mission Beach.

I-2: [...] vive en San Diego.

- At the end of the presentation, another student makes an attempt to present information in Spanish. Since the following class interaction is carried out in English as inter-sentential switch, I-2 interjects in Spanish. 
3. Class activity—drawing a picture of an alien:

I-2: OK, vamos a usar la parte [...]

- In order to gain the students' attention, I-2 uses tag-switching at the beginning of the sentence.

I-2: Nuestro extraterrestre tiene cinco orejas.

s: I think it's ears, I think it's five ears.

- Directions about drawing come in Spanish. Students unsure of the word meaning discuss it among themselves in English, attempting to translate the sentence.

S: How many bocas?

I-2: Cinco bocas.

- The student asks about the number of mouths that has to be drawn on the sketch of the alien by using the English structure of question and inserting a Spanish word at the end. -2 responds to the question in Spanish.

4. Supplemental materials in the textbook:

I-2: Chicos, supplemental material por favor

- I-2 gives instructions to switch to a different activity and for clarity does so by intra-sentential switch with the English words inserted in the middle of a Spanish sentence.

I-2: ¿Porqué? Emotional state. Physical, mental, emotional state.

- Students are doing a grammar activity where they have to discuss their answers in pair. One student asks I-2 for clarification of a grammar concept. I-2 does so in Spanish and then reinforces the answer by a question in Spanish followed by a rule spelled out in English implementing inter-sentential switch (alternation) stating that a certain verb always require a certain grammatical tense.

I-2: Chicos, clase: mientras esperaba - while she was waiting

- While doing the grammar exercise about imperfect tense I-2 gets the class attention and first repeats the answers given by students, then continues by using inter-sentential CS, saying it in English as well to make sure that the concept is clear enough.

S: sal.... Would it be imperfect?

I-2: ¿Chicos, pretérito o imperfecto? 
- Instead of responding directly to the student's question in English, I-2 asks the whole classroom in Spanish to find the answer to the question.

5. Students showing drawings of aliens to the rest of class:

S: Do you want me to show it?

I-2: Sí, claro.

- The student is asked to present the drawing of the alien; the student asks in English about the use of projector to show the drawing, I-2 confirms in Spanish.

S: El gato.

-2: ¿El what?

- The student mixes up words for 'mouth' and 'cat' in Spanish, to which $1-2$ reacts by intra-sentential CS, partially in Spanish and partially in English.

S: Is it corazón, the heart?

I-2: Corazón - the heart

- The student performs intra-sentential switch (insertion) while asking for reassurance from 1-2. I-2 responds by repeating the Spanish word, then using its English form.

I-2: ¿Dónde está el cerebro?

s: I forgot that one.

- When the student is asked about an element missing from the picture, the student answers in English the question posed in Spanish by I-2. Inability to perform his action seems to be caused by the lack of vocabulary.

S: Do I have to name it all?

I-2: Yes, claro.

- A similar situation has happened earlier, but here I-2, instead of responding in Spanish only, responds partially in Spanish and partially in English. It can be argued, since it occurred at the end of the class, that the switch was either triggered by a previous sentence or produced by fatigue.

\subsubsection{Class observations - Intermediate Level Spanish - I-3}

The observed class followed a certain structure based on the course work that consisted of two blocks - review and textbook activity. Around 10 examples of CS were observed; the most prominent examples are listed in this section. Spanish text appears in italics. 


\section{Review:}

I-3: ...la actualidad de los medios de comunicación del otro país y allí hay algunos clips and that's the part I have to figure out, no me acuerdo si es lunes o martes...

- 1-3 explains to the class that one part of the exam will consist of listening comprehension based on a clip from the news. I-3 performs an intra-sentential switch, alternating between Spanish and English by using congruent lexicalization.

\section{I-3: $[\ldots]$ OK, $[\ldots]$}

- Tag-switching inserted at the end of the Spanish discourse by I-3 as a discourse marker.

I-3: Y yo comienzo a llorar porque es el final de semestre y os voy a echar de menos. It happens sometimes. Entonces ¿hay preguntas de lo que vamos a hacer las últimas semanas?

- 1-3 does inter-sentential switch by inserting a sentence in English (alternation). This switch serves as a closure of previous topic and the next sentence in Spanish changes back to the main topic of the class-review.

I-3: Sí, hoy es la fecha límite.

S1: OK, so it's like six-page assignment on [school platform], we would screenshot all of the pages...

I-3: Sí y luego mandarlo en un email o imprimirlos está bien también, me da lo mismo.

S2: Should we not just screenshot pages where it says like $96 \%$ or whatever? Or every single page?

I-3: Yeah, well, I think that was your question too, [...] all I need is the first screen with the title and then the end scores. Did I answer you? [...] OK, comenzamos ahora.

- First, l-3 explains in Spanish when and how the assignment should be submitted. The student starts asking in Spanish but when he runs out of vocabulary he switches to English; l-3 at first maintains the conversation in Spanish but, when the second student joins the conversation, he also switches to English to make sure that the instructions are clear and understood by the students. Tag-switching performed at the end of I-3's English discourse represents a way to return to the Spanish context.

\section{Activity from a textbook:}

I-3: Si ganaras la lotería ¿qué harías?

S: Me comprara una casa.

I-3: Muy bien. ¿Una casa grande?

S: No, un pequeño.

I-3: Mejor, muy bien. 
S: Because the taxes...

I-3: Los impuestos

s: Los impuestos estén muy poquito.

- I-3 maintains Spanish conversation with the student until the point when the student is unsure about vocabulary and switches to English. I-3 provides him with answer in Spanish and the student continues with the conversation. I-3 neither emphasizes nor corrects mistakes that occurred during production.

I-3: Mis padres estarían más contentos conmigo si...

S: I don't know if I'm doing this right, me graduara en uno más año.

I-3: Sí, si me graduara en un año más.

- 1-3 asks a question in Spanish to which the student responds by intra-sentential switch (alternation), asking for clarification. I-3 reassures and corrects the student by recast.

I-3: Si pudieran hablar con el presidente, que le dicen... [...]

S: I would just start ranting.

I-3: Puedes decir el verbo quejarse. Entonces si pudiera hablar con el presidente...

- 1-3 asks a question in Spanish to which the student responds in English. I-3 retakes the conversation in Spanish and offers the student possible vocabulary.

\subsection{Categorization and possible reasons for students' use of CS}

Gathering of naturalistic data through recording of the classroom interaction allowed for the following interpretation as seen in figure 1, based on type and frequency of CS produced by students during the observed classes.

\section{FIGURE 1}

Code switching examples by students in the L2 classroom

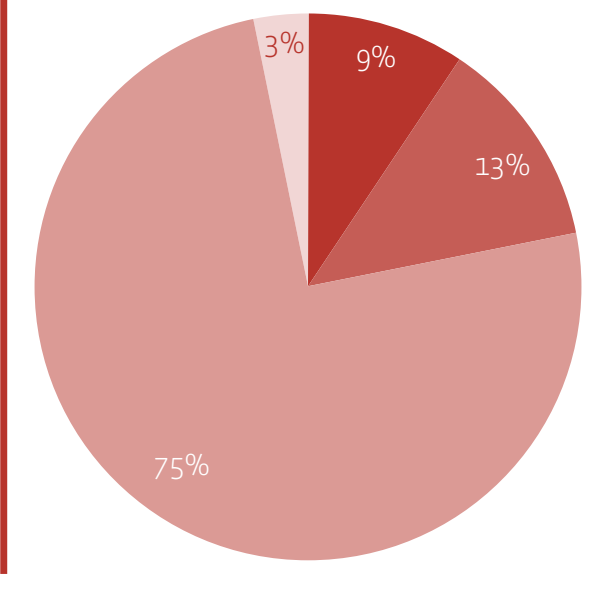

Tag swiching
Insertion
Alternation
Congruent lexicalization 
In line with the bilingual proficiency notion, the tendency to use insertion and alternation together with tag switching (i.e., oh, ok) by students has been observed in both lower level classes (Beginner Level Spanish with balanced early bilingual instructor and Continuation of Beginning Spanish with late bilingual - native speaker of Spanish instructor). The Intermediate Level class students (with late bilingual - native speaker of English instructor) used alternation only and did not engage in any other type of CS. Congruent lexicalization appeared in Continuation of Beginning Spanish and it was most likely triggered by the interactive character of the class.

Besides the language level of students the choice of materials used in class had an influence on their production of CS. The students who produced the most CS examples of alternation belonged to the Continuation of Beginning Spanish class, which can be contributed to the teaching method and resources used in class. The students engaged in PPT presentations and drawing activity that required them to interact freely with the instructor (late bilingual - native speaker of Spanish) and each other more than in the classes where mainly the textbook was used. The Beginner Level Spanish class made exclusive use of textbook and grammar exercises, which caused extended use of CS on the part of the instructor (balanced early bilingual), but lower use on the part of the students. The students in the Intermediate Level Spanish taught by the instructor (late bilingual - native speaker of English) who also worked with the textbook resorted to the use of synonyms instead of CS whenever possible.

As detailed below, there were various possible reasons for students' use of CS in the L2 classroom:

\section{1) Common L1}

Macaro (2006: 67) mentions that CS practice is quite common in the classes where $\mathrm{LI}$ is the same for all the learners, leading to its use in tasks and activities where students' collaboration is required. This was applicable to the Beginner Level Spanish class; however, I have observed that in the Intermediate Level Spanish students intended and succeeded in using mostly Spanish in their collaborative oral activities, trying to practice the concepts learned in class. Therefore, it could be stated that the CS use decreased with increased language level of students.

\section{2) Task management}

Students often code switch when it comes to the task management "to compensate for the lack of linguistic knowledge" since they do not possess what Macaro (2006: 67) calls "management language'. Their limited vocabulary causes problem and, when it comes to the performance of the task, they turn to the CS practice in order to explain the procedure or describe the results. This has been observed in the Continuation of Beginning Spanish class, in the drawing activity, when students were faced with instructions different from those appearing in the textbook and they often switched codes for clarification. 
3) Negotiation of meaning

When students were faced with unknown vocabulary, they tended to code switch by the use of alternation. This has been related to the lack of 'management language', which impeded them from posing the question in $\mathrm{L} 2$. In the interest of avoiding misunderstanding, the students rather continued in L1. As stated by Macaro (2006: 77), "learners may have to codeswitch in order to use the teacher as a resource and to manage their task". This has been observed both in Beginning Spanish and Continuation of Beginning Spanish class. In the Intermediate Level Spanish class, the students preferred either to use synonyms or to modify their answer without CS practice, drawing from their extended vocabulary. It could be argued that this technique is not applicable in the classes with lower language level; therefore, students in those classes turned to the use of CS.

\subsection{Interviews with instructors (I-1, I-2, I-3)}

After the class observations were finished, instructors were asked to participate in a short semi-structured interview that was recorded. The main aim of the interview was to determine if the instructors were conscious of their own CS practice and the CS practice of their students in the classroom. Another area of focus was how did their language background influence their decision to switch code during the class. In the transcription of each interview, emphasis was placed on their acquisition or learning of Spanish and English and exposure to the second language. I believe that this has had a major influence on the CS occurrences during the class observation. Questions asked during the interview were as follows:

- What is your language background?

- How long have you been teaching?

- How would you define your approach to language class teaching - what is your language preference for giving directions to students?

- What is the main reason for CS in your classroom? When does it occur? Who initiates it?

- What is your reaction if students engage in CS-do you correct them or not? Do you respond in L1 or L2?

- What is your general attitude towards CS — do you perceive it as positive/negative/beneficial/unnecessary?

As the interview was semi-structured, more questions were asked in some cases, based on the responses from each particular instructor.

\subsubsection{Interview about CS perception with I-1 - balanced early bilingual}

Instructor (I-1) was an early balanced bilingual - Spanish/English language pair with native language Spanish and C2 level proficiency in English. He has been exposed to Spanish language since birth; however, he has not been formally schooled in Spanish language up until 
high school. He then continued his study of Spanish throughout his tertiary education. In addition, in middle school I-1 also studied French. He has been teaching Spanish first in high schools and then moved to teaching at the university level. Up to date I-1 has been teaching for seven years.

When asked about his approach to the language class teaching, I-1 stated that his preference of language for giving directions depended on the level of the class. In case of beginner class, he first tried to use cognates and the words they might understand to guide them and sometimes accompanied this strategy with the use of gestures, as could be seen in an example in section 3.4.1 where the prompt to read is a hand gesture. If this strategy did not work, l-1 would resort to use of English. In more advanced classes I-1 adhered to Spanish only.

When asked about the main reason for CS in his classroom, I-1 responded that he used CS to give instructions and to achieve better understanding. He mainly used CS when the topic of the class was grammar. This can be seen in section 3.4.1 in an example when the I-1 uses following sentence structure:

I-1: Only! En inglés tenemos what is happening right now, ¿verdad? Tenemos what is happening over period of time $y$ what is going to happen, yeah? Pero en español [...] simple present tense, right?

I-I felt that it was very important for the students to understand how the grammar rule functioned in their first language so they could relate it to the rule in Spanish. When they did not completely understand the rule, it became hard for them to grasp the idea of the grammar point.

In response to the question about students who engage in CS, I-1 encouraged students to speak in Spanish when they were working together. Unfortunately, this was not always possible and sometimes English was used during group activities. He acknowledged that in the beginner classes it was hard for students to speak Spanish exclusively. When l-1 asked students to use Spanish, he also provided them with examples of simple Spanish phrases for everyday communication. His intention was to not interrupt conversations; neither did he reproach students for use of English. I-1 stated that for students' benefit it was important to do what they felt was comfortable for them.

When asked in what language he responded when students engaged in CS, I-1 answered that it depended on the situation. This can be seen in section 3.4.I where the reply comes in Spanish:

S: How do you use that? I-1: Estoy llendo a la biblioteca.

He affirmed the idea that clarification questions about grammar points would be answered in English together with referring to situations when original explanation took place, such as in this example in section 3.4.1: 
I-1: Está hablando con su amiga because that is what she is doing right now. S: Isabel es la abuela y está jugando el ajedrez con su hija. I-1: Isabel es la abuela, right? Y está jugando, right? Because that's what she is doing right now.

In case of questions about spelling, I-1 would spell the word in Spanish. In case of the question 'how do you say this' his answer would be preceded by the Spanish phrase 'cómo se dice' since he believed that it was important for students to recognize the basic questions such as 'cómo se dice' or 'cómo se escribe' in Spanish.

The last question asked about the general attitude towards the CS. I-1 personally did not perceive CS as a negative phenomenon; however, he felt that he should suppress the want to use CS, mainly due to his teacher training, where instructors were advised not to engage in such practice. The idea was that not two but only one language should be used in the language classroom. However, he also recognized that in case of beginner class CS was inevitable. I-1 concluded that use of English in the second language classroom was necessary to a limit and needed to be controlled by specific rules. In regards to his own CS practice I-1 stated that CS was something that happened subconsciously when he was too involved in the classroom process. He attributed it to the influence of being submerged from the early age in a bilingual environment where both languages were used in parallel.

\subsubsection{Interview about CS perception with I-2 - late bilingual (Spanish/En- glish)}

Instructor (I-2) was a late bilingual - Spanish/English language pair with native language Spanish and C2 level of proficiency in English. She has been educated in Spanish and started to learn English as a second language at school; however, she considered that she formally started to learn and speak English only when she was about thirty years old. She has been teaching for several decades now and the last 15 years she has been teaching Spanish Ianguage. I-2 was proficient in both languages but had slight preference for Spanish, as this was her L1.

When asked about her approach to the language class teaching, I-2 stated that she used a communicative approach since the research has shown that concentrating on grammar is not that beneficial for students. In response to language preference when giving directions to students, I-2 responded that she usually used Spanish unless she saw that the students did not understand, at which point she felt that she had to switch to English; this can be seen in the example in section 3.4.1 where the first response from the instructor comes in Spanish:

\section{S: sal.... Would it be imperfect? I-2: ¿Chicos, pretérito o imperfecto?}

As her main reason to use CS in the classroom, I-2 indicated that it was the facial expression of students that prompted her to switch from Spanish to English. 
In response to who initiates the $\mathrm{CS}, \mathrm{I}-2$ answered that it was mainly done by students who switched to English. It occurred when they did not possess the necessary vocabulary to respond to the question in Spanish as observed in this example in section 3.4.1:

I-2: Nuestro extraterrestre tiene cinco orejas. S: I think it's ears, I think it's five ears.

However, even if students spoke to I-2 in English, she still responded in Spanish, as seen in the following example in section 3.4.1:

S: Do you want me to show it? I-2: Sí, claro.

Her strategy was to keep speaking in Spanish and use the phrase 'qué significa esto' to accompany her discourse. This phrase worked as trigger for students - when used by I-2 it indicated that they had to translate their answer into Spanish. They did so as a group, which in turn helped those students who did not understand to keep up.

When she was questioned as to what was her reaction if students engaged in CS, 1-2 responded that there were no corrections done by her. She stated that she disagreed with correcting and very seldom engaged in this activity. If a student made a serious mistake, she tried to correct them afterwards in the way of engaging the whole classroom and not focusing on the individual student. Her reasoning was that she did not want the students to believe that they were doing something wrong. The strategy was to teach the whole classroom the correct version of the word in Spanish. This can be seen in section 3.4.1 when the English version of the date was inserted in the form of intra-sentential switch by the student and I-2 waited until the presentation was finished, engaging the whole class in finding an equivalent in Spanish to the word 'two thousand twelve':

\section{S: $[\ldots]$ in two thousand twelve $[\ldots]$ I-2: ¿Cómo se dice two thousand twelve?}

When requested to give answer about her attitude towards CS, I-2 responded that she found CS to be a necessary phenomenon. In her opinion, CS served as a tool for better understanding, therefore working together with the idea of comprehensive input. Students at all times should understand what the instructors were doing to get the best out of the class. I-2 stated that simple immersion in a foreign language without understanding did not help students in their learning process. When they understood, they progressed better. To illustrate the point, this example in section 3.4.1 deals with clarification of grammar concept:

I-2: Chicos, clase: mientras esperaba - while she was waiting.

When asked if she would encourage other teachers to use CS in their classes, she responded that she was opposed to deliberate use of it unless it was indispensable to the teaching process. The ideal teacher for $1-2$ would be the one who was able to carry out the class entirely in 
Spanish, without the need to use CS. However, when she was questioned about the students she admitted that the model of an ideal student who only speaks Spanish in the class was idealized and that CS was necessary in certain situations to ensure the understanding by students.

In response to preference of intra-sentential versus inter-sentential CS, I-2 responded that her preference would be for inter-sentential CS. Reason given for this choice was that the intra-sentential switch made the discourse more difficult to understand and therefore interfered with learning.

\subsubsection{Interview about CS perception with I-3 - late bilingual (English/Spanish)}

Instructor (I-3) was a late bilingual - English/Spanish language pair with English as his native language. He started to learn Spanish throughout his formal schooling and later studied Spanish literature and culture. He participated in the Study Abroad program that helped him to improve his proficiency. During his tertiary studies, I-3 undertook teaching college level students. He also has intermediate level of Portuguese. I-3 has been teaching Spanish for the past sixteen years.

When asked about his approach to the language class teaching, I-3 stated that the main focus of Spanish classes is presented as getting the students to the language proficiency level. However, he maintained the idea of increasing linguistic proficiency together with the cultural proficiency and ability to be more self-reflective. In his classes, he tried to introduce various cultural elements to increase awareness and empathy. Those were sometimes presented in English to ensure that students understood them. In his opinion, both culture and language influenced the ways of conceptualizing the world. This notion is similar to the relationship between bilingualism and biculturalism as mentioned by Francoise Grosjean (1982: 157) in his book Life with Two Languages. An Introduction to Bilingualism, where he quotes Haugen, who argued that a person, albeit using two languages, could in fact be monocultural.

In response to what was his language preference when giving directions to students, I-3 answered that it was Spanish. The idea was to use as much Spanish in the class as possible with two exceptions-either the case of grammar explanation, or a very complex activity that presented the problem of time constraint. In both cases, the instructions would come in English. This can be seen in the example in section 3.4.1 when I-3 starts the explanation in Spanish but later switches to English to simplify the process and ensure full understanding:

I-3: Sí, hoy es la fecha límite. S1: OK, so it's like six-page assignment on [school platform], we would screenshot all of the pages... I-3: Sí y luego mandarlo en un email o imprimirlos está bien también, me da lo mismo. S2: Should we not just screenshot pages where it says like 96\% or whatever? Or every single page? I-3: Yeah, well, I think that was your question too, [...] all I need is the first screen with the title and then the end scores. Did I answer you? [...] OK, comenzamos ahora. 
I-3 considered grammar as a critical point where switching to English to explain concepts was necessary. He felt that telling the students about grammar entirely in Spanish when they were not sure about the concept and might have trouble to grasp it even in English was counterproductive to the clarity of information.

When requested to give answer about main reason for CS in his classroom, I-3 stated that the CS produced by students resulted from the lack of the vocabulary and practice, observable in this example in section 3.4.1:

I-3: Si pudieran hablar con el presidente, que le dicen... [...] S: I would just start ranting. I-3: Puedes decir el verbo quejarse. Entonces si pudiera hablar con el presidente...

It became visible when students tried to convey information about topics such as what they did over the weekend. I-3 felt that the CS came from wanting to share all the information quickly and accurately in the same way as they did in English. In Spanish, they needed to look for adequate words and grammar structure and were still prone to mistakes. As per his own CS practice, I-3 responded that it usually happened when he came across an unfamiliar word -in such situation he responded in English. He felt that his CS was quite well-controlled and did not occur subconsciously unless he was physically tired. This occurrence has been documented in the field of CS research and named as 'the phenomenon of the most available word' (Grosjean, 1982: 151).

In response to what his reaction would be when students engaged in CS, I-3 answered that his reaction depended on the context. In situations when students were using too much English within their answer, I-3 used nonverbal clues such as coughing to remind students of Spanish language preference. In case that the use of CS persisted, he would gently interrupt the discourse while maintaining the playful tone as not to discourage the students.

Another question was if the response from a student in English triggered the answer from I-3 in the same language. I-3 responded that if the topic were grammar, he would acknowledge the question in Spanish, as can be seen in the example in section 3.4.1:

I-3: Mis padres estarían más contentos conmigo si... S: I don’t know if I'm doing this right, me graduara en uno más año. I-3: Sí, si me graduara en un año más.

Then he would switch to English for particular explanation. He did that since he felt that it took up less time than to do it in Spanish. Nevertheless, he was positive that the CS of the student would not trigger the language of his answer.

When asked about his general attitude towards CS, I-3 stated that his long-term exposure to language teaching made him to perceive CS situation as something natural. He maintained a clear distinction between avoiding CS if possible within the classroom environment and 
freely engaging in CS practice whenever in group of bilinguals. He did not regard students' CS as a bad practice, but would not encourage them to engage in it. CS was a concern since the aim of the class was to increase their language proficiency; therefore, there was a tendency to avoid it or revert them back to the target language.

\section{Conclusions}

Based on the recording and analysis of data obtained from observation of usual classroom activity I reached several conclusions. First of all, response to the research question of what is the aim of CS in second language classroom is that it serves to enhance communication. On the one hand, instructors are expected to express themselves with clarity and ensure that the class has received and understood the prompts. The need to avoid ambiguity and verify the understanding by students generates the switch from L2 to L1. All three instructors agreed on the point of using CS for grammar explanations as they felt that understanding the concept was more important than dwelling on the use of $L 2$. Therefore, it is possible to conclude that CS in the case of instructors acts as a tool that enhances their ability to explain concepts that might be perceived as ambiguous by students when spoken about in L2 only. On the other hand, students responding to instructions usually possess a lower level of oral skills in the second language. Their understanding is higher than their ability to produce a full sentence or recall a word; therefore, they resort to CS. CS for them functions as a communication tool that enables them to express themselves freely; they switch because they lack other resources. Edmondson (2004: 157) further elaborates on this subject by arguing that in the classroom environment students engage in CS to bridge the gap in knowledge while teachers engage in 'language switching' in order to accommodate students' needs.

Second, as an answer to the research question if the instructor's native language influences their CS practice, I conclude that the instructor's native language has a considerable effect in the process of CS. Compiled data proved some of the assumptions established at the beginning of the research and supplied evidence for influence of native language on CS practice of the instructors. Similarities in pattern were observed with the native speaker of Spanish and English. Their use of CS was less frequent and more controlled. They engaged in the practice only seldom when they needed to provide students with vocabulary and occasionally clarify grammar or instructions. As indicated by the instructor with Spanish as native language, keeping the CS down to a minimum and refraining from alternation was done to avoid confusion it could cause to students. In contrast with the previous two instructors, the balanced early bilingual produced the most of CS examples in form of tag-switching, insertion, congruent lexicalization and alternation, disapproving my assumption that his CS would be a result of conscious choice. It appears that his ability to use two languages at the same level allowed him to seamlessly alternate in the way of intra-sentential CS; however, he was not completely conscious of his production of CS examples. 
Third, in regards to the research question of a relationship between CS and proficiency of second language learners, a clear correlation between CS practice of students and their proficiency of second language was observed at each level of the class. The beginners' level class was the one that produced the most CS examples in general, by both students and the instructor. As the level of classes rose, the number of CS examples became less frequent. Contrary to the instructors who tend to used intra-sentential CS and tag switching, students engaged more in inter-sentential CS. Use of tag-switching was quite low by students thorough the three courses, but widespread by instructors who used it as a discourse marker to get students' attention. Even though students implemented CS as a tool to express themselves in a second language, it should be used with caution in the second language classroom. When abused by students, CS practice could lead to fossilized errors since students would rely too much on the practice of 'crutching' and lose motivation for further improvement.

To sum up, data obtained from this study support notions that appear in the research focused on bilingualism and use of CS. According to Gardner-Chloros (2009: 172), CS "has functions within Speech and Language Accommodation”. Thanks to CS, speakers with different lexical skills are able to engage in communication. The concept of CS as a tool to enhance communication rather than practice that should be abolished has been affirmed by Grosjean, who said that "what monolinguals fail to understand is that lexical borrowing and code switching are quite simple the result of the bilinguals need to communicate with one another" (1982: 330).

Aside from benefits, this study has its limitations. One of them is the sample size. Observations were carried out in classes of which each varied in number of students. This had an impact on method implemented by instructors in order to accommodate students and to avoid delays in explanation. No previous survey was conducted to investigate if classes included heritage speakers of Spanish or to specify language level of each individual student. The time span of observations was limited within one week which influenced materials used and discussed in class and consequently the students' performance.

In order to further expand this study it would be beneficial to conduct another observation in the same university and compare obtained data with the original data to see how difference in materials used in classroom, number of students and location within academic calendar influence the CS practice. As well as that, it would be interesting to conduct the same study in a similar size university but located in a different area of the US. There is a high possibility that teaching methods, class size and language level would vary depending on the area, which consequently would affect the CS of students and instructors alike.

Equally important as listing benefits and limitations of the study is the necessity to highlight its importance. As I mentioned at the beginning, creating corpus of CS occurrences that could be further used by researchers is rather challenging. Data obtained in language laboratories through questionnaires do not reflect the natural process of CS production. Classroom 
observation without interference of researcher as presented in this study is the closest to simulation of natural conditions. Even though specific in its nature, I believe that CS examples compiled in this study can be of interest to researchers focused on bilingualism, second language acquisition and teaching methods of second language.

\section{Cited bibliography}

Auer, Peter (ed.), 1998: Code-switching in conversation. Language, interaction and identity, New York: Routledge.

Barnwell, David, 2008: "The Status of Spanish in the United States", Language Culture and Curriculum 21 (3), 235-243.

Basnight-Brown, Dana, and Jeanette Altarriba, 2007: "Chapter 4. Code-Switching and Code-Mixing In Bilinguals: Cognitive, Developmental, and Empirical Approaches" in Alfredo ArdiLLA and Elaine Ramos (eds.): Speech and Language Disorders in Bilinguals, Nova Science Publishers, Inc., 69-89.

Bazo, Plácido, 1996: “Chapter 2. Student Characteristics” in Neil McLaren and Daniel MadRID (eds.): A Handbook for TEFL, Alcoy: Editorial Marfil, 39-63.

Bullock, Barbara E., and Almeida Jacqueline ToRıBı (eds.), 2009: The Cambridge Handbook of Linguistic Code-switching, Cambridge: Cambridge University Press.

EDMONDSON, Willis, 2004: "Code-switching and world-switching in foreign language classroom discourse" in Juliane House and Jochen ReHbeIn (eds.): Multilingual Communication. Volume 3 of Hamburg Studies on Multilingualism, Amsterdam/Philadelphia: John Benjamins Publishing, 155-178.

Gardner-Chloros, Penelope, 2009: Code-switching, New York: Cambridge University Press.

Grosjean, Francois, 1982: Life with Two Languages. An Introduction to Bilingualism, Harvard: Harvard University Press.

Grosjean, Francois, 2002: "Interview on bilingualism" [http://www.francoisgrosjean.ch/interview_en.html, accessed: 16 March 2017].

Gullberg, Marianne, Peter Indefrey and Pieter Muysken, 2009: "Research techniques for the study of code-switching" in Barbara E. Bullock and Almeida Jacqueline ToRIBıo (eds.): The Cambridge Handbook of Linguistic Code-switching, Cambridge: Cambridge University Press, 21-39.

HancoCk, Mark, 1997: "Behind Classroom Code Switching: Layering and Language Choice in L2 Learner Interaction”, TESOL Quarterly 31 (2), 217-235. 
Hinnenkamp, Volker, 2005: "Semilingualism, Double Monolingualism and Blurred Genres - On (Not) Speaking a Legitimate Language”, The Journal of Social Science Education 4 (1), 57-90.

Liebscher, Grit, and Jennifer Dalley-O'CaIn, 2005: "Learner Code-Switching in the Content-Based Foreign Language Classroom”, The Modern Language Journal 89 (2), 234-247.

MaCARo, Ernesto, 2006: "Chapter 5. Codeswitching in the L2 Classroom: A Communication and Learning Strategy" in Enric LLURDA (ed.): Non-Native Language Teachers: Perceptions, Challenges and Contributions to the Profession, NY: Springer Science+Business Media, 63-84.

MacSwan, Jeff, 1999: A minimalist approach to intrasentential code switching, New York: Garland Publishing, Inc.

Mursken, Pieter, 2000: Bilingual Speech. A typology of code-mixing, Cambridge: Cambridge University Press.

Pfaff, Carol W., 1979: "Constraints on Language Mixing: Intrasentential Code-Switching and Borrowing in Spanish/English”, Language 55 (2), 291-318.

Treffers-Daller, Jeanine, 2009: "Code-switching and transfer: an exploration of similarities and differences" in Barbara E. BuLlock and Almeida Jacqueline ToriBı (eds.): The Cambridge Handbook of Linguistic Code-switching, Cambridge: Cambridge University Press, 58-74. 